Original Research Article

\title{
A comparative study of the efficacy and tolerability of parenteral ceftriaxone and cefotaxime in pediatric population for acute bacillary dysentery in a tertiary care hospital
}

\author{
Sagar K.*, Shanmukananda P., Veena D. R., Shwetha H.
}

Department of Pharmacology, Dr. B. R. Ambedkar Medical College, Bangalore, Karnataka, India

Received: 04 February 2018 Accepted: 07 March 2018

*Correspondence to:

Dr. Sagar K.,

Email: sagardvg@gmail.com

Copyright: (C) the author(s), publisher and licensee Medip Academy. This is an openaccess article distributed under the terms of the Creative Commons Attribution NonCommercial License, which permits unrestricted noncommercial use, distribution, and reproduction in any medium, provided the original work is properly cited.

\begin{abstract}
Background: Diarrheal disorders in childhood account for a large proportion $(18 \%)$ of childhood mortality. Among diarrheal diseases, dysentery is a major cause of childhood morbidity and mortality, especially in developing countries. Methods: This is an open labelled, prospective, randomised, comparative study carried out at Dr. B. R. Ambedkar Medical College Hospital, Bangalore from November 2014 to November 2015 after Institutional Ethics Committee approval. A total of 80 Paediatric patients who met the inclusion criteria were included in the study after taking written informed consent from parents and assigned into two groups, Group A- Inj. Ceftriaxone (50-100mg/kg/day) and Group B- Inj. Cefotaxime (100 mg/kg/day) in divided doses for a period of 3-5 days based on requirement.

Results: In this study, Cefotaxime was non inferior to Ceftriaxone as the Mean

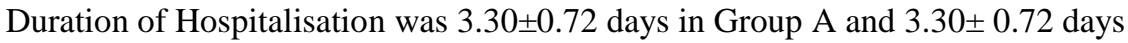
in Group B with p value of 1.000, showing no statistically significant difference. Both were well tolerated without any reports of ADR (Adverse Drug Reaction). Conclusions: In this study shows that Inj. Cefotaxime is equally efficacious and well tolerated as Inj. Ceftriaxone in the treatment of Acute Bacillary Dysentery in paediatric patients.
\end{abstract}

Keywords: Acute bacillary dysentery, Cefotaxime, Ceftriaxone, Efficacy, Tolerability

\section{INTRODUCTION}

Diarrhoeal diseases are a leading cause of childhood morbidity and mortality in developing countries, and an important cause of malnutrition. In 2003 an estimated 1.87 million children below 5 years died from diarrhoea. 8 out of 10 deaths occur in the first two years of life. ${ }^{1}$

The term gastroenteritis denotes infections of gastrointestinal tract caused by bacterial, viral or parasitic pathogens usually are food borne illnesses. ${ }^{2}$

Among diarrheal diseases, dysentery is a major cause of childhood morbidity and mortality, especially in developing countries in Africa, Asia, and Central and Latin America. Bloody diarrhea (dysentery) and persistent diarrhea with malnutrition are also important causes of death. $^{3}$

The term dysentery is used to describe the syndrome of bloody diarrhea with fever, abdominal cramps, rectal pain, and mucoid stools. ${ }^{4}$

Antimicrobial therapy is the mainstay in developing countries where prolonged and recurrent episodes of dysentery can decrease the nutritional status and growth of affected children. ${ }^{5,6}$ 
As recommended by WHO, Inj. Ceftriaxone is the agent of choice for the treatment of acute bacillary dysentery which belongs to third generation Cephalosporins. Since there are few studies on Cefotaxime usage in bacillary dysentery management, this study is undertaken to compare the efficacy, tolerability of both. ${ }^{5}$

\section{METHODS}

\section{Source of data}

The study was conducted in the Department of Paediatrics at Dr. B. R. Ambedkar Medical College and Hospital, Bangalore. Only Inpatients who met the following inclusion criteria were included in the study. The duration of the study was from November 2014 to November 2015.

\section{Inclusion criteria}

- Children aged between 6 months to 14 years presenting with dysentery (loose stools with visible blood or mucus).

- Both sexes.

\section{Exclusion criteria}

- Children with known causes of blood in stools like rectal polyps, inflammatory bowel disease and bleeding diathesis.

- $\quad$ Presence of shock, abdominal distension, severe malnutrition.

- Primary or secondary immunodeficiency.

- $\quad$ Presence of any other medical condition that might adversely impact the safety of the study participants or confound the study results.

- History of hypersensitivity or allergy to Penicillin or Cephalosporins.

\section{Study design}

This was an open labelled, prospective, randomised, comparative study carried out at Dr. B. R. Ambedkar Medical College Hospital, Bangalore from November 2014 to November 2015. After approval from the Institutional Ethics Committee, the study investigated the efficacy and tolerability along with cost effectiveness of Inj. Ceftriaxone and Inj. Cefotaxime in the treatment of Acute Bacillary Dysentery in Paediatric Population. A total of 80 Paediatric patients who met the inclusion criteria were included in the study and divided into two groups. Informed consent was taken from parents and Informed assent from adolescents. Group A received Inj. Ceftriaxone $(50-100 \mathrm{mg} / \mathrm{kg} /$ day) in divided doses (twice daily) and Group $B$ received Inj. Cefotaxime $(100 \mathrm{mg} / \mathrm{kg} / \mathrm{day})$ in divided doses (thrice daily) for a period of 3-5 days based on requirement. Clinically successful treatment was defined as complete resolution of clinical signs and symptoms of dysentery. Cost effective analysis was carried out by comparing direct costs of antibiotics used for treatment. The drug costs were derived from standard reference (CIMS 38 ${ }^{\text {th }}$ year, July- Oct 2016) source.

\section{Statistical analysis}

Descriptive and inferential statistical analysis has been carried out in the present study. Results on continuous measurements are presented on Mean \pm SD (Min-Max) and results on categorical measurements are presented in Number (\%). Significance is assessed at 5\% level of significance.

Chi-square/ Fisher Exact test has been used to find the significance of study parameters on categorical scale between two or more groups.

\section{RESULTS}

\section{Disposition of patients}

A total of 80 Paediatric patients took part in the study, Group A - 40 patients received Inj. Ceftriaxone (50$100 \mathrm{mg} / \mathrm{kg} /$ day) and Group B- 40 patients received Inj. Cefotaxime $(100 \mathrm{mg} / \mathrm{kg} /$ day) in divided dose for 3-5 days.

\section{Demographic and baseline characteristic features}

The age distributions in both groups were well matched without significant difference as shown in Figure 1. Majority of the patients were in the age group of $1-5$ years (60\% in Group A and $47.5 \%$ in Group B).

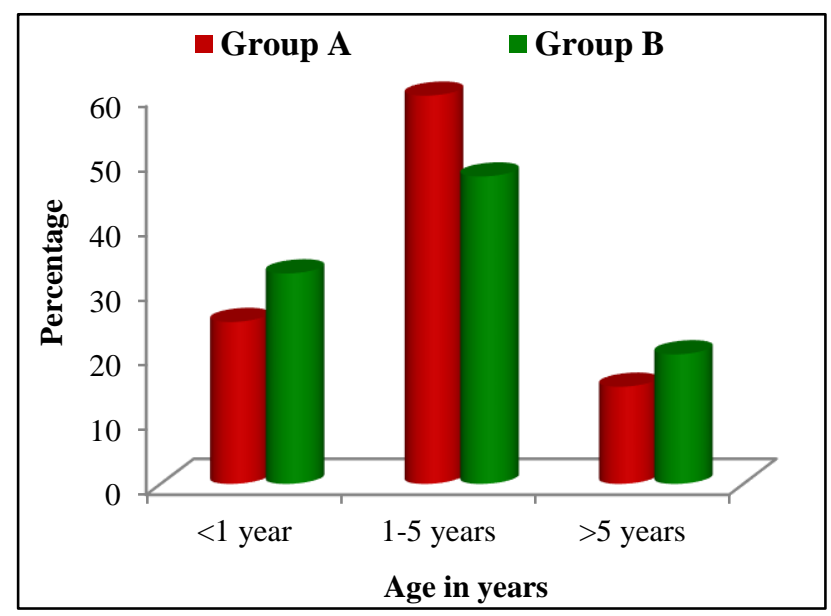

Figure 1: Age distribution of the patients studied.

There were more male patients in both the group $(67.5 \%$ in Group A and 65\% in Group B) compared to female patients (32.5\% in Group A and 35\% in Group B) as shown in Figure 2.

Immunisation status were assessed at the time of admission $92.5 \%$ of both group paediatric patients immunised properly to the age, $7.5 \%$ were partially immunised. 


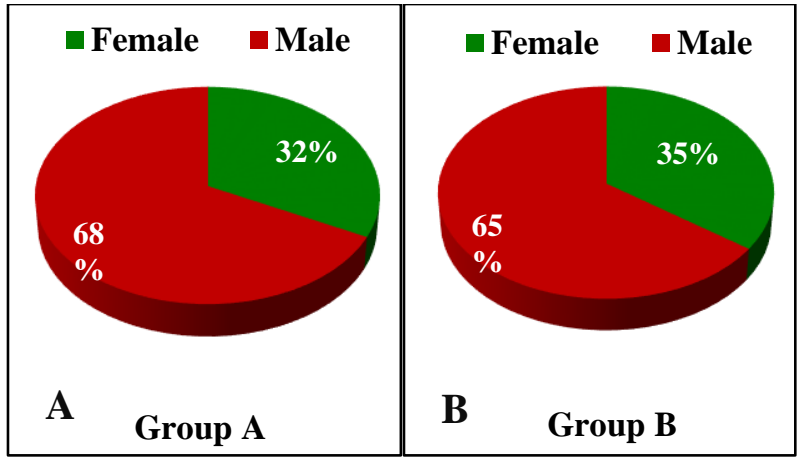

Figure 2 (A and B): Gender distribution of the patients studied.

Dehydration status was assessed according to WHO guidelines, $62.5 \%$ of group and $55 \%$ of Group B were Mild to Moderately dehydrated (some dehydration), $15 \%$ of both group severely dehydrated and $22.5 \%$ of Group A and $30 \%$ of Group B were less dehydrated as shown in Figure 3.

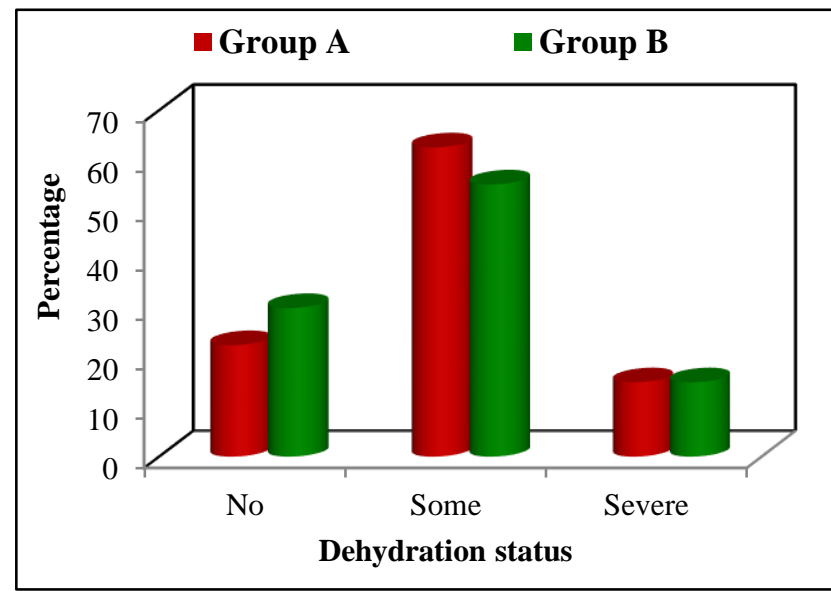

Figure 3: Dehydration status in the two groups of patients studied.

Before assigning patients to the group, stool analysis was done. Stool sample with blood and mucus were considered for the study and also stool analysis was done to see presence of bacteria and other pathogens, in which $65 \%$ of Group A and $62.5 \%$ of Group B showed bacteria in the stool analysis as shown in Table 1.

Table 1: Blood and mucus and stool analysis for the bacteria in two groups of patients studied.

\begin{tabular}{|llll|}
\hline $\begin{array}{l}\text { Investigation - } \\
\text { stool analysis }\end{array}$ & $\begin{array}{l}\text { Group A } \\
(\mathbf{n = 4 0})\end{array}$ & $\begin{array}{l}\text { Group B } \\
(\mathbf{n = 4 0})\end{array}$ & $\begin{array}{l}\text { Total } \\
(\mathbf{n = 8 0})\end{array}$ \\
\hline $\begin{array}{l}\text { Blood and } \\
\text { mucus }\end{array}$ & $40(100 \%)$ & $40(100 \%)$ & $80(100 \%)$ \\
\hline Bacteria & $26(65 \%)$ & $25(62.5 \%)$ & $51(63.8 \%)$ \\
\hline
\end{tabular}

Clinically paediatric patients were assessed, history of loose stool, vomiting and other associated symptoms noted and then assigned into both groups and treated.

\section{Efficacy evaluation}

Efficacy - the primary end point was assessed in both groups in the form of Duration of stay - clinical improvement i.e., reduction in loose stool episodes, absence of nausea and vomiting, absence of associated symptoms like fever, abdominal pain and tenesmus and getting discharged from hospital. 85\% (34) of both group patients got discharged within 3 days whereas $15 \%$ (6) of patients were discharged after 5 days (>3days) as shown in Table 2 and Figure 4 with p value of 1.000, Not significant, showing Inj. Cefotaxime is equally efficacious as Inj. Ceftriaxone.

Table 2: Duration of stay (days) in the two groups of patients studied.

\begin{tabular}{|llll|}
\hline $\begin{array}{l}\text { Duration of } \\
\text { stay (days) }\end{array}$ & Group A & Group B & Total \\
\hline$<3$ & $34(85 \%)$ & $34(85 \%)$ & $68(85 \%)$ \\
\hline$>3$ & $6(15 \%)$ & $6(15 \%)$ & $12(15 \%)$ \\
\hline Total & $40(100 \%)$ & $40(100 \%)$ & $80(100 \%)$ \\
\hline
\end{tabular}

$\mathrm{P}=1.000$, Not significant, Fisher Exact test

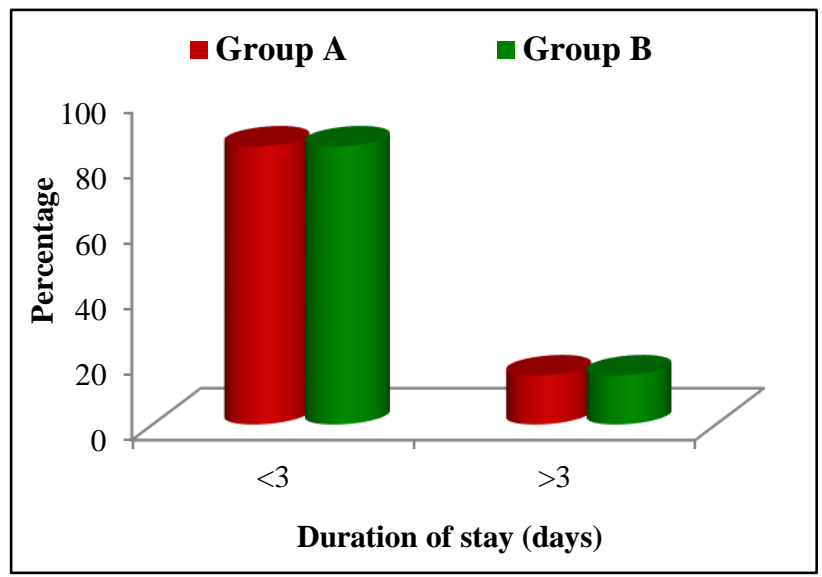

Figure 4: Efficacy evaluation-duration of stay in two groups.

\section{Safety evaluation}

Both treatment regimens were well tolerated during the study. Not even a single patient reported adverse effects during the course of treatment with $\mathrm{p}$ value of 1.000 as shown in Table 3 and Figure 5. However, the observations were not statistically significant. There were no serious adverse events (SAE) during the study period.

Table 3: Adverse effect in the two groups of patients studied.

\begin{tabular}{|llll|}
\hline Adverse effect & Group A & Group B & Total \\
\hline Not Reported & $40(100 \%)$ & $40(100 \%)$ & $80(100 \%)$ \\
\hline Reported & $0(0 \%)$ & $0(0 \%)$ & $0(0 \%)$ \\
\hline Total & $40(100 \%)$ & $40(100 \%)$ & $80(100 \%)$ \\
\hline
\end{tabular}

$\mathrm{P}=1.000$, Not significant, Fisher Exact test 


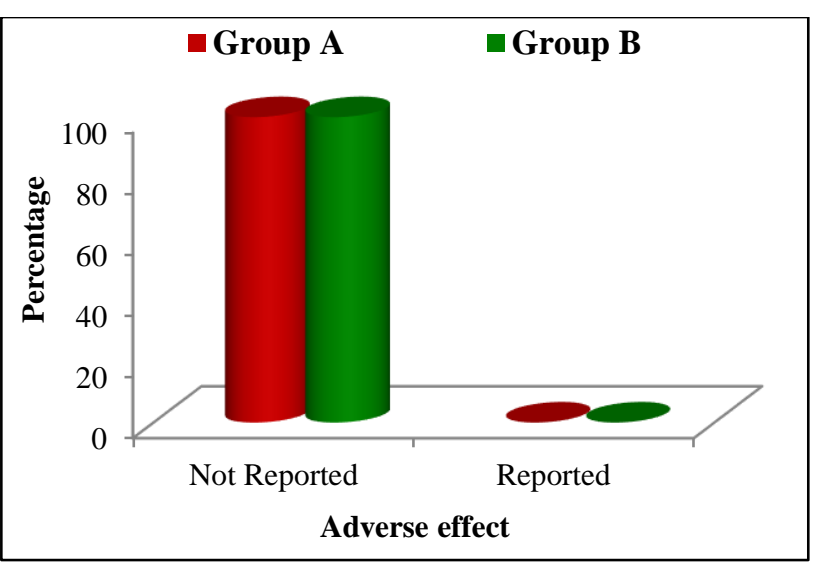

Figure 5: Adverse effect in the two groups of patients studied.

\section{DISCUSSION}

According to WHO, the agent of choice for the treatment of acute bacillary dysentery are fluoroquinolones, third generation Cephalosporins and Pivmecillinam. ${ }^{7}$

Previous studies like Mei Qu et al, Rodriguez RS et al, and Alam An et al, showed the development of resistance to following class of antibiotics like Naldixic acid, Trimethoprim- Sulfamethoxazole, Penicillin's and second generation Cephalosporins too.

All the quinolones caused transformations in the immature cartilage of joints that carry weight in all of the animal species that have been studied; toxicity is detected clinically through symptoms of acute arthritis, pain, swelling and gait disturbances. ${ }^{8,9}$ These lesions are constant and didn't regress even after discontinuation of therapy. Arthralgia and joint swelling have been documented in certain case series in children along with fluid collection. ${ }^{10}$ Indication for use of fluoroquinolones in children mainly gastroenteritis due to multidrug resistant microorganisms. ${ }^{11}$

Previous studies have compared Ceftriaxone monotherapy with other classes of antibiotics which demonstrated superiority of Ceftriaxone over those. Studies have shown that there is development of resistance to the other classes of antibiotics. So, Inj. Ceftriaxone remains the agent of choice for management of acute bacillary dysentery.

Inj. Cefotaxime is a third generation cephalosporin, having the same mechanism of action and spectrum. ${ }^{12-14}$ Only few studies have been taken up where Inj. Cefotaxime was used in the management of acute bacillary dysentery.

This study was undertaken to show that Inj. Cefotaxime is equally efficacious and well tolerated as Inj. Ceftriaxone in the treatment of acute bacillary treatment. India being a developing country these types of studies are needed, so well tolerated and equally efficacious drug can be recommended for the management of disorders like acute bacillary dysentery in paediatric patients.

Results show that Inj. Cefotaxime is equally efficacious and well tolerated as Inj. Ceftriaxone in the treatment of acute bacillary dysentery ( $p$ value 1.000) the difference was not statistically significant.

\section{CONCLUSION}

Overall, in this study shows that Inj. Cefotaxime is equally efficacious, well tolerated and cost effective when compared to Inj. Ceftriaxone in the treatment of Acute Bacillary Dysentery in paediatric patients.

The continuous surveillance of multidrug resistant strains is very important to know the changing antibiotic susceptibility pattern as well as the cyclical change of the serogroup from time to time as the resistance pattern also changes with the change in the serogroup. Analysis and periodic reporting is important in proper therapy of Shigellosis.

\section{Funding: No funding sources}

Conflict of interest: None declared

Ethical approval: The study was approved by the Institutional Ethics Committee

\section{REFERENCES}

1. Bhutta ZA. Acute Gastroenteritis in Children. Robert M. Kliegman, Richard E. Behrman, Hal B. Jenson, Bonita F. Stanton: Nelson Textbook of Paediatrics: 17th edition: Elsevier Publication, New Delhi, India: Chapter 196 (1191- 93) and Chapter 337(1605-1618).

2. Gaeza JM, Cohen MB. Infectious Diarrhea. Robert Wyllie, Jeffrey S. Hyams, Marsha Kay. Paediatric Gastrointestinal and Liver Disease. Elsevier Saunders Publication, $4^{\text {th }}$ Edition, chapter 39; 2006:405-422.

3. Dutta D, Bhattacharya MK, Dutta S, Datta A, Sarkar D, Bhandari B, et al. Emergence of Multidrug resistant Shigella dysenteriae type 1 Causing Sporadic Outbreak In and Around Kolkata, India. J. Health Popul. Nutr. 2003:21(1):79-80.

4. Rajeshwari K, Mishra M, Dubey AP, Uppal B, Anuradha S. Spectrum of dysentery in children presenting to a tertiary level teaching hospital in New Delhi. International Journal of Medicine and Medical Sciences. 2013 Apr 30;5(4):158-62.

5. Camilleri M, Murray JA. Diarrhea and Constipation. Dennis L. Kosper, Anthony S. Fauci, Stephen L. Hauser et al. Harrison's Principles of Internal Medicine. Mc Graw hill Education publication. 19 Edition, Part 2: Chapter 55; 2015:264-268.

6. Taneja N. Changing Epidemiology of Shigellosis and Emergence of Ciprofloxacin Resistant Shigellae in India. J. Clin. Microbiol. 2007;45(2):678-9.

7. Traa BS, Fischer Walker CL, Munos M, Black RE. Antibiotics for the treatment of dysentery in children; Inte J of Epidemio. 2010;39(1):70-4. 
8. Burkhardt JE, Walterspiel JN, Schaad UB. Quinolone Arthropathy in Animals Versus Children: Clinical Infectious Diseases, The University of Chicago. 1997;25:1196-204.

9. Chalumeau M, Tonnelier S, d'Athis P, Tréluyer JM, Gendrel D, Bréart G, et al. Fluoroquinolone safety in pediatric patients: a prospective, multicenter, comparative cohort study in France. Pediatrics. 2003 Jun 1;111(6):e714-9.

10. Sendzik J1, Lode H, Stahlmann R. Quinolone-induced arthropathy: an update focusing on new mechanistic and clinical data: International Journal of Antimicrobial Agents. 2009 Mar;33(3):194-200.

11. Velissariou IM. The use of fluoroquinolones in children: recent advances. Expert review of antiinfective therapy. 2006 Oct 1;4(5):853-60.

12. Petri WA. Pencillins, Cephalosporins, and other $\beta$ Lactam antibiotics. Laurence L. Brunton, BruceA. Chabner, Bjorn C. Knollmann: Goodman and
Gilman's The Pharmacological Basis of Therapeutics: 12th edition: Mc Graw Hill Publication, New York, USA. Chapter 53; 2011:1493-1503.

13. Rang HP, Dale MM, Ritter JM. Rang and Dale's Pharmacology: $8^{\text {th }}$ Edition: Elsevier publication, Spain: Chapter 50; 2015:624-628.

14. Lupoli T, Hooper DC, Arnaout RA, Kahne D, Walker S, Pharmacology of Bacterial and Mycobacterial Infections: Cell Wall Synthesis. Bertram G. Katzung, Anthony J. Trevor. Basic and Clinical Pharmacology. $13^{\text {th }}$ Edition, McGraw Hill Education, Section VIII, Chapter 43; 2015:776-780.

Cite this article as: Sagar K, Shanmukananda $\mathrm{P}$, Veena DR, Shwetha H. A comparative study of the efficacy and tolerability of parenteral ceftriaxone and cefotaxime in pediatric population for acute bacillary dysentery in a tertiary care hospital. Int J Basic Clin Pharmacol 2018;7:1109-13. 